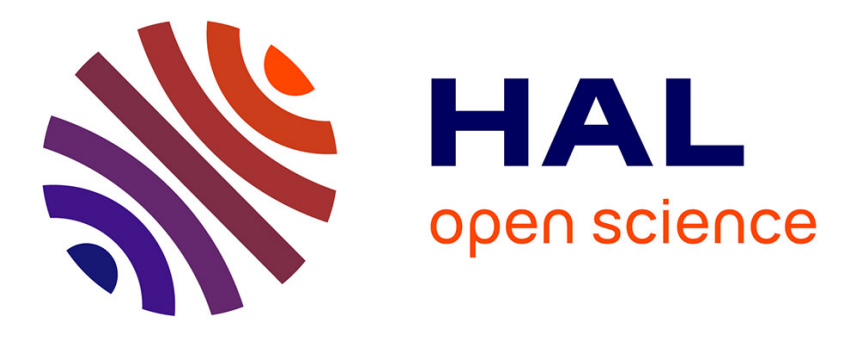

\title{
Serum soluble CD23 levels in giant cell arteritis'
}

Pascal Roblot, Franck Morel, Eric Lelièvre, Marie-Hélène Biais-Sauvètre, Donat de Groote, Jl Preud'Homme, Jean Claude Lecron

\section{To cite this version:}

Pascal Roblot, Franck Morel, Eric Lelièvre, Marie-Hélène Biais-Sauvètre, Donat de Groote, et al.. Serum soluble CD23 levels in giant cell arteritis'. Immunology Letters, 1996, 53 (1), pp.41. 10.1016/0165-2478(96)02612-0 . inserm-03549093

\section{HAL Id: inserm-03549093 https://www.hal.inserm.fr/inserm-03549093}

Submitted on 31 Jan 2022

HAL is a multi-disciplinary open access archive for the deposit and dissemination of scientific research documents, whether they are published or not. The documents may come from teaching and research institutions in France or abroad, or from public or private research centers.
L'archive ouverte pluridisciplinaire $\mathbf{H A L}$, est destinée au dépôt et à la diffusion de documents scientifiques de niveau recherche, publiés ou non, émanant des établissements d'enseignement et de recherche français ou étrangers, des laboratoires publics ou privés. 


\title{
Serum soluble CD23 levels in giant cell arteritis $^{1}$
}

\author{
Pascal Roblot $^{\mathrm{a}, *}$, Franck Morel ${ }^{\mathrm{b}}$, Eric Lelièvre ${ }^{\mathrm{b}}$, Marie-Hélène Biais-Sauvètre ${ }^{\mathrm{b}}$, \\ Donat de Groote ${ }^{\mathrm{c}}$, Jean-Louis Preud'homme ${ }^{\mathrm{b}}$, Jean-Claude Lecron ${ }^{\mathrm{b}}$ \\ aService de Medecine Interne, Chu la Miletrie, BP577, 86021 Poitiers Cedex, France \\ ${ }^{\circ}$ Laboratoire D'Hormonologie/URA CNRS 1172, Chu Poitiers, France \\ ${ }^{\mathrm{c} B i o s o u r c e}$ Europe SA, Fleurus, Belgium
}

Received 16 July 1996; accepted 31 July 1996

\begin{abstract}
Lymphocytes and monocytes express various levels of membrane-bound CD23, the low affinity receptor for $\operatorname{IgE}$ (FceRII), and in some cases release it as a soluble form. Soluble CD23 (sCD23) has been implicated in the regulation of many immunological functions of $\mathrm{T}$ and $\mathrm{B}$ lymphocytes, macrophages and myeloid cells in humans. To study serum SCD23 levels in inflammatory conditions, we selected a systemic disease sensitive to corticotherapy, the giant cell arteritis, which is characterized by an inflammation of the temporal artery. Serum sCD23 levels, as measured by a radioimmunoassay, were increased in these patients, and returned to normal values within the $24 \mathrm{~h}$ following initiation of corticotherapy. The data suggest that the increase in sCD23 levels in giant cell arteritis results from an overproduction.
\end{abstract}

Keywords: Giant cell arteritis; Soluble CD23; Inflammation; Corticotherapy

\section{Introduction}

Giant cell arteritis (GCA) is a vasculitis syndrome affecting the blood vessels, the walls of which contain significant amounts of elastic tissue, as the superficial temporal, ophtalmic and posterior ciliary arteries. Arterial biopsies reveal a panarteritis with inflammatory infiltration by $\mathrm{T}$ lymphocytes, macrophages and giant cells. There is an important chronic inflammatory syndrome with increased levels of acute phase proteins, including haptoglobin, $\alpha 1$ acid glycoprotein and C-reactive protein (CRP). Glucocorticoids usually induce a dramatic and rapid improvement of clinical symptoms whereas pathological lesions may persist for several months. The etiology of GCA remains obscure. How-

\footnotetext{
* Corresponding author. Tel.: + 3349 444324; fax: + 3349 444383.

${ }^{1}$ This work was supported by CNRS, Poitiers Univcrsity Hospital (clinical research grant), and Region Poitou-Charentes.
}

cver, it has been suggested that cell-mediated immunity might be involved in the disease $[1,2]$.

The $45 \mathrm{kDa}$ CD23 surface antigen was first described as a $B$ cell restricted antigen expressed at high density by Epstein-Barr virus transformed lymphoblastoid cell lines and cells from chronic lymphocytic leukemia, and at a low density by normal B cells. CD23 was then identified as the low-affinity receptor for $\operatorname{IgE}(\mathrm{Fc} \in \mathrm{RII})$ and found to be also weakly expressed on monocytes/ macrophages, eosinophils, platelets, follicular dendritic cells, Langherans cells, thymic epithelial cells and $T$ cells [3]. CD23 is a member of the superfamily of type $\mathrm{C}$ animal lectins and it is a type II glycosylated transmembranous protein [4]. On the other hand, a 25 $\mathrm{kDa}$ stable soluble form of the CD23 molecule (sCD23) is spontaneously shed from the surface of most CD23bearing cells such as lymphoblastoid or activated normal B cells [3]. Human sCD23 still reacts with anti-CD23 monoclonal antibodies and binds IgE. Interestingly, several biological activities have been ascribed to $\mathrm{SCD} 23$, such as the control of human IgE synthesis, 
the regulation of $\mathrm{B}$ and $\mathrm{T}$ lymphocyte differentiation and proliferation, the differentiation of myeloid precursors and germinal centers B cells, and the inhibition of monocyte migration [3]. Recently, sCD23 has been described as an enhancer of monokine release by purified monocytes $[5,6]$ and indirectly a potent costimulator of IL- 2 or IL-12 induced IFN- $\gamma$ production by resting $T$ lymphocytes [6].

sCD23 is detectable in normal sera. High levels of serum CD23 have been reported in hematological malignancies such as chronic lymphocytic and hairy cell leukemias [7]. In allergy and inflammatory diseases involving a B cell response, such as rheumatoid arthritis, Sjögren's syndrome, systemic lupus erythematosus or Kawasaki disease, increased levels of sCD23 have been reported also $[8-11]$. Serum sCD23 levels are also high in dialysed chronic uremic patients [12]. The aim of this study was to analyse serum levels of sCD23 in a chronic inflammatory disease before and during corticotherapy.

\section{Materials and methods}

Twenty-five patients with biopsy-proven GCA were included in this prospective study, after informed consent. They were given $1 \mathrm{mg} \cdot \mathrm{kg}^{-1} \cdot \mathrm{day}^{-1}$ prednisone (two thirds of the dosage at $0800 \mathrm{~h}$, one third at $1200 \mathrm{~h}$, no more than $60 \mathrm{mg} \cdot$ day $^{-1}$ ) during the first month of therapy with a progressive reduction during the next months. Blood samples were obtained at $0800 \mathrm{~h}$, before treatment and after 1,7 and $30 \pm 2$ days of treatment. For three patients, samples were also obtained 4, 8, 12 and $36 \mathrm{~h}$ after the initiation of steroid therapy. Sera were frozen and stored in aliquots at $-20^{\circ} \mathrm{C}$ before assay. Control samples were obtained from 20 healthy volunteers, seven patients suffering from acute bacterial pneumonia before any treatment (acute inflammation controls) and 11 patients suffering from necroziting vasculitis.

In addition to regular biological investigations, serum CRP, haptoglobin and $\alpha 1$ acid glycoprotein levels were

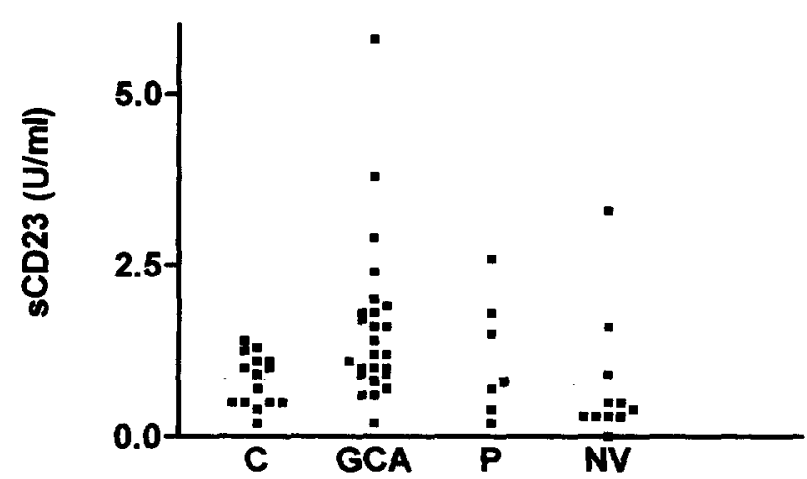

Fig. 1. Serum sCD23 levels $(\mathrm{U} / \mathrm{ml})$ in healthy volunteers $(C)$, GCA patients before treatment, patients with acute pneumonia $(P)$, and necroziting vasculitis (NV). Means are indicated as solid bars.

determined by nephelemetry (Behring, Rueil-Malmaison, France). Serum sCD23 levels were measured in duplicate using a radio-immunosorbent assay with monoclonal antibodies which recognize 25 to $37 \mathrm{kDa}$ sCD23 fragments, with a detection threshold of 0.3 $\mathrm{U} / \mathrm{ml}(1 \mathrm{U}=5 \mathrm{ng} / \mathrm{ml}$, Biosource Europe SA, Fleurus, Belgium). Serum IL-6 levels were measured using ELISA kits, kindly provided by Dr. J. Wijdenes (INNOTEST, Besançon, France).

Results are shown as means \pm standard error of mean (S.E.M.). Normal values were defined as the ranges of mean \pm 2 standard deviations of normal control serum levels. Results were compared using the Student's $t$-test for paired and unpaired data. Correlation analysis werc carricd out using Spearman corrclation coefficients.

\section{Results and discussion}

Serum sCD23 levels were elevated on D0 in GCA patients by comparison with healthy volunteers $(P<$ 0.01 ) (Fig. 1). In contrast, they were not significantly affected in the two other inflammatory states studied, infectious pneumopathy and necroziting vasculitis (Fig. 1), despite a similar increase in CRP levels in all cases (data not shown). A marked inflammatory response

Table 1

Effect of corticosteroid therapy on serum sCD23 levels and other serum parameters in 25 GCA patients

\begin{tabular}{lccccc}
\hline & NC & D0 & D1 & D7 & D30 \\
\hline $\mathrm{SCD} 23(\mathrm{U} / \mathrm{ml})$ & $0.82 \pm 0.09$ & $1.6 \pm 0.24$ & $0.87 \pm 0.16$ & $0.88 \pm 0.15$ & $0.59 \pm 0.07$ \\
$\mathrm{IL}-6(\mathrm{pg} / \mathrm{ml})$ & $3.3 \pm 0.9$ & $59.4 \pm 18$ & $17.6 \pm 5.5$ & $14 \pm 4.4$ & $10.3 \pm 2.5$ \\
$\mathrm{CRP}(\mu \mathrm{g} / \mathrm{ml})$ & $<2.3$ & $91 \pm 9.6$ & $54.4 \pm 9$ & $8.7 \pm 2.6$ & $7.9 \pm 3.2$ \\
$\alpha 1 \mathrm{GP}(\mathrm{mg} / \mathrm{ml})$ & $0.4-1.2$ & $2.28 \pm 0.13$ & $2.23 \pm 0.2$ & $1.63 \pm 0.12$ & $1.46 \pm 0.09$ \\
Haptoglobin $(\mathrm{mg} / \mathrm{ml})$ & $0.5-3.2$ & $6.65 \pm 0.29$ & $6 \pm 0.35$ & $5 \pm 0.27$ & $3.72 \pm 0.33$ \\
AP $(\mathrm{mIU} / \mathrm{ml})$ & $53-120$ & $318 \pm 39$ & ND & $325 \pm 54$ & $177 \pm 12$ \\
Creatinine $(\mathrm{nmol} / \mathrm{ml})$ & $40-120$ & $79 \pm 7$ & ND & $99 \pm 11$ & $83 \pm 4$ \\
\hline
\end{tabular}

Measurements performed prior to and 1, 7 and 30 days (D0, D1, D7 and D30) after initiation of the treatment (mean \pm S.E.M.). NC, normal controls; $\alpha 1$ GP, $\alpha 1$ acid glycoprotein; AP, alkaline phosphatase; CRP, C-reactive protein. 


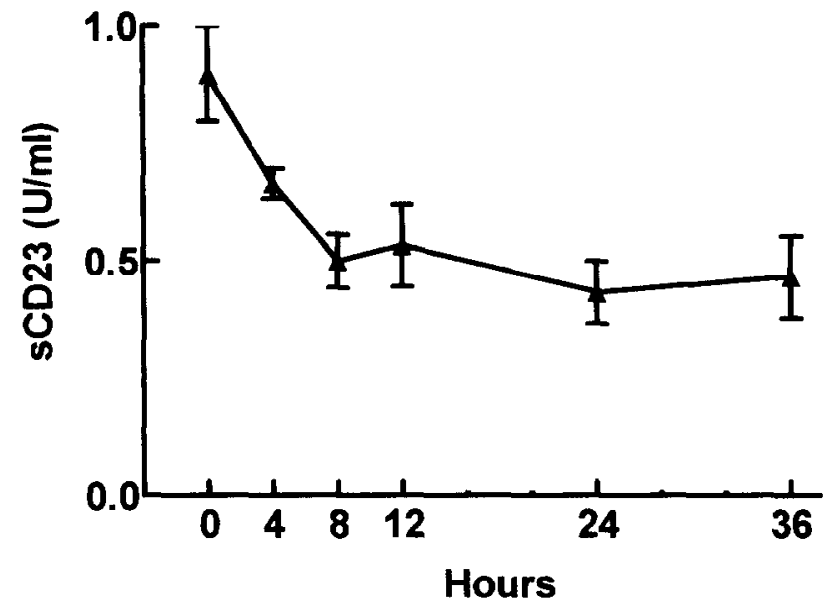

Fig. 2. Evolution of serum SCD23 levels $(\mathrm{U} / \mathrm{ml})$ in GCA patients before and $4,8,12,24$ and $36 \mathrm{~h}$ after initiation of corticosteroid therapy. Results are indicated as mean \pm S.E.M.

was observed on D0 (day 0), with high serum CRP, haptoglobin and $\alpha 1$ acid glycoprotein levels (Table 1). IL-6 levels were also elevated, as previously described [13]. Serum sCD23 levels correlated with IL-6 levels on D0 $(r=0.81, P<0.001)$, but not with $\alpha 1$ acid glycoprotein, haptoglobin and CRP levels. Such a correlation between IL- 6 and $\mathrm{SCD} 23$ has been previously reported in dialysed chronic renal failure patients [12]. It could be of interest since sCD23 enhances IL-6 production by human monocytes in vitro [5]. On the other hand, sCD23 levels and serum alkaline phosphatase activity did not correlate despite the moderate cholestasis observed in $2 / 3$ of these patients with GCA. Intercstingly, serum sCD23 and creatinin levels corrclated on D0 $(r=0.69, P=0.0004)$, in spite of the absence of noticeable renal failure in these patients.

Within the first $24 \mathrm{~h}$ following the onset of prednisone therapy, sCD23 levels reached normal control values in all but one patient and the difference between values recorded on D0 and Dl was significant $(P<$ 0.01 ) (Table 1). No further differences were observed between SCD23 levels on D1 (day 1) and D7 (day 7), or between D1 and D7 compared to normal control values. In contrast, $\mathrm{sCD} 23$ levels on D30 (day 30) are significantly decreased $(P<0.05)$ when compared to normal control values. A decrease was also observed for IL-6 levels within the first $24 \mathrm{~h}$ but not for CRP. Short kinetic monitoring revealed that sCD23 sera levels decreased as soon as $4 \mathrm{~h}$ following initiation of corticosteroid therapy, suggesting a direct action of prednisone on CD23 synthesis or release and a short half-life for $\mathrm{sCD} 23$ in vivo (Fig. 2). Interestingly, we recently observed that $10^{-5} \mathrm{M}$ prednisolone in vitro decreases SCD23 release by a lymphoblastoid B cell line (data not shown), as previously shown for peripheral blood lymphocytes [14]. Taken together, these data suggest that high serum sCD23 levels in GCA patients results from an overproduction of the molecule rather than from a decrease in its clearance. Nevertheless, the cellular origin of sCD23 in GCA remains to be identified. We searched for but could not evidence differences of $\mathrm{CD} 23$ expression by peripheral blood mononuclear cells from healthy volunteers and GCA patients (data not shown). Since CD23 positive lymphocytes have been detected in the skin lesions from atopic dermatitis patients [15], it will be of interest to study sCD23 expression at the level of the arterial lesions. Interestingly, it has been recently suggested that sCD23, if produced locally, may participate in the initiation and in the maintenance of a non reactive inflammatory response triggered by foreign antigens [6]

In other inflammatory diseases, high sCD23 levels have been found in autoimmune diseases involving a $\mathrm{B}$ cell response such as rheumatoid arthritis. systemic erythematosus lupus or primary Sjögren's syndrome. In rheumatoid arthritis, sCD23 levels correlate with the titer of rheumatoid factors [9]. It has been suggested that the increase of sCD23 in these diseases reflects B lymphocyte activation. GCA is considered to be associated with a Thl response [2] and serum IgE levels are normal (data not shown). Hence, GCA seems to be an inflammatory disease mediated by $\mathrm{T}$ cells and associated with high serum $\mathrm{sCD} 23$ levels, a previously unreported situation. Whether increased serum SCD23 levels in GCA result from a lymphocyte or monocyte activation and the possible role of $\mathrm{sCD} 23$ in the physiopathology of the disease by modulating lymphocyte or monocyte functions remain opened questions. Interestingly, in type II collagen-induced arthritis in mice, a model for human rheumatoid arthritis, a successful disease modulation has been achieved by treatment with antibodies to murine sCD23 [16]

\section{References}

[1] Weyand, C.M., Schönberger, J., Oppitz, U., Hunder, G.G. Hicok. K.C. and Goronzy, J.J. (1994) J. Exp. Med. 179, 951.

[2] Weyand, C.M., Hicok, K.C.. Hunder, G.G. and Goronzy, J.J. (1994) Ann. Intern. Med. 121, 484.

[3] Delespesse, G., Suter, U., Mossalayi, D., Bettler, B., Sarfati, M. Hofstetter, H., Kilsherr, E. and Dalloul, A. (1991) Adv. Immunol. 49,149

[4] Kikutani, H., Invi, S., Sato, E., Barsumian, H.. Owaki, K. and Yamasaki, K. (1986) Cell 47, 657.

[5] Herbelin, A., Elhadad, S., Ouaaz, F.. de Groote, D. and Descamps-Latsha, B. (1994) Eur. J. Immunol. 24, 1869.

[6] Armant, M., Rubio, M., Delespesse, G. and Sarfati, M. (1995) J. Immunol. 155, 4868.

[7] Sarfati, M.. Bron, D., Lagneaux, L., Fonteyn, C., Frost, H. and Delespesse, G. (1988) Blood 71, 94.

[8] Mastumoto, T., Miike, T., Yamaguchi, K., Murakami, M., Kawabe, T. and Yodoi, J. (1991) Clin. Exp. Immunol. 85, 288.

[9] Rezonzew. R. and Newkirk, M.M. (1994) Clin. Immunol. Immunopathol. 71. 156. 
[10] Matsubara, T., Furukawa, S., Motohashi, T., Okumura, K. and Yabuta, K. (1995) Eur. J. Pediatr. 154, 826.

[11] Bansal, A., Roberts, T., Hay, E., Kay, R., Pumphrey, R.S.H. and Wilson, P.B. (1992) Clin. Exp. Immunol. 89, 452.

[12] Descamps-Latscha, B., Herbelin, A., Nguyen, A.T., de Groote, D., Chauveau, P., Verger, C., Jungers, P. and Zingraff, J. (1992) Kidney Int. 43, 878 .
[13] Roblot, P., Morel, F., Lelievre, E., Gascan, H., Wijdeness, J. and Lecron, J.C. (1996) J. Rheumatol. 23, 410.

[14] Fischer, A. and König, W. (1990) Immunology 71. 473.

[15] Sakamato, T., Tagikawa, M., Tamamori, T., Horiguchi, D. and Yamada, M. (1990) J. Invest. Dermatol. 95, 592.

[16] Plater-Zyberk, C. and Bonnefoy, J.Y. (1995) Nalure Med. 1, 781. 